\title{
THE EFFECT OF SELF-CONCEPT, MOTIVATION AND DISCIPLINE ON THE PERFORMANCE OF THE PRIMARY SCHOOL PRINCIPALS AT JAKARSA REGENCY OF SOUTH JAKARTA
}

\author{
Heru Sriyono \\ Unindra jakarta \\ Herusriyono30@gmail.com
}

\begin{abstract}
This research was about the effects of self-concept, motivation and discipline on the performance of the primary school principals at Jagakarsa regency of South Jakarta. The objectives of this research were: determining whether self-concept has a direct effect on discipline, determining whether motivation has a direct affect on discipline, determining whether discipline has a direct effect on performance, determining whether the self-concept has direct effect on performance, determining whether the motivation has a direct effect on performance, determining whether the self-concept has an indirect effect on performance but through discipline, and determining whether the motivation have an indirect effect on performance through discipline. The research was conducted by survey method with path-analysis. The sample size was 63 principals of the school. The result are as follows : (1) that the selfconcept directly affect the discipline of the principals; (2) the motivation directly affect their discipline, and (3) the discipline directly affect their performance, therefore, improvement of performance of to the principal should be improved by enhancing the rules and working standard.
\end{abstract}

Keyword: self-concept, motivation, discipline, school-principal's performance

The Government has increased the quality of education through changes in the education system, improving the quality of human resources through training and upgrading of teachers, improvement of infrastructure, and improvement of school management and procurement of equipment, textbooks and creates a good working discipline. To make the education and the teaching has better quality at school, required a better and professional performance of a school principals, because the reciprocation of education at the school depends on the competence of principals in leading the teachers.

The expected professional skills of an elementary school principal who acts as a teacher too according Soedijarto (1993: 88) are: (1) mastering the materials; (2) managing the teaching and learning program; (3) managing the classroom; (4) using the media or other learning sources; (5) mastering the foundations of education; (6) managing the teaching and learning interactions; (7) assessing the achievements for the benefit of teaching; (8) knowing the functions and programs, guidance and counseling services; (9) 
identifying and maintaining the administration of the school; and (10) understanding and interpreting the results of research for the purpose of teaching.

The opinion can be interpreted that every professional and well perform school principal, must have the ability, as required above, and has a self-concept in action.

Therefore, every school principal is required to be competent in carrying out his duties as manager of the school, and the performance of the principal of a good school is certainly very influenced by the self-concept and motivation. This is consistent with the objectives to be achieved, and the motivation that is in the principal must come from within himself called intrinsic motivation, and sourced from outside himself called an extrinsic motivation.

In implementing leadership, a principal has a direct or indirect influence on the duties of teachers. School principals who are able to work regularly and have good selfconcept will be able to realize a good working discipline, firm, fair, attentive, and will encourage subordinates to work well and finally will produce optimal results.

Good performance for the principals could be interpreted as encouragement to work better. The will and working performance are influenced by motivation, higher interest, and needs, so as to make principals more enthusiasm in work and able to accept the challenge.

The fact that there are still many principals aimed merely got the position, yet worked as a leader. And school leadership has not been fully accepted by his subordinates, and also there are many teachers who need to be couched.

This study is limited to the performance of the principal. The set of variables that affect the performance of the principal variables are variables that discipline as an endogenous variable, while the variable self-concept and motivation as exogenous. So the purpose of this study was to determine the effect of self-concept, motivation, and discipline on the performance of school principals. Hopefully, this study can be useful to provide empirical data and information which can be used practically and theoretically. In this section will also be translated also theories referenced in this study as follows.

The definition of performance is expressed by Stephen P. Robbins translated by Benyamin Molan (2003: 59) states that performance is the ability of employees or the ability of workers. Meanwhile, according to Anwar Prabu M (2003: 9) said that performance is the quality of work that can be achieved through experience, education, training, and development work. From the above opinion is known that a job requires the ability and suitability of the work of a worker. Most likely the performance will be 
adequate when the work was rewarded with the appropriate person, and a visible optimal performance through his work is supported by the competence or the quality of its capabilities. K.H. Toto Tasmara (2006: 54) states that competence is the ability of the seeds to be nurtured and watered through a variety of teaching and training, her work in earnest, face challenges. Competence is built not in one day, but it is a chain of curiosity is very deep.

Based on the definitions given above, can be seen that the performance is viewed from different angles, that is willingness to carry out work tasks and skills in the form of action. Seen from the perspective illustrates that many factors affect a person's performance, some of them are: (1) a person's spirit and motivation, (2) a person's competencies and skills (Maslow, 2003: 244; Edwin Locke, 2003: 227). A competent leader is not innate, as claimed by K.H. Toto Tasmara (2006: 56) that the competent leader did not come about easily, but it is a long journey of his life career. Competence leader shows his professionalism.

The opinions above shows that a competent person is a person always learn to maintain the quality of its capabilities. To complement the competencies and skills of a person, the need for critical elements that are closely related to a person's competencies and skills, namely: a. credibility; b. confident; c. consisten; d. creative (Kouzes and Posner, 2003: 28; Dick Grote, 1992: 3; Stephen R. Covey, 2005: 353; Stephen P. Robbins (2005: 353 ) states that creativity is the ability to produce new ideas and useful.

Based on the theories above, the writer has a conception that the performance of the principal is in accordance with the performance capabilities of the principal for carrying out their role as principal, which can be measured through encouragement, motivation, and activities.

In relation to employment, self-concept affects the performance. According to the theory proposed path Robert House (2005: 353) explains that the behavior of the leader of the directive (the concept itself) give specific guidance on its performance. In the form of images can be seen as follows:

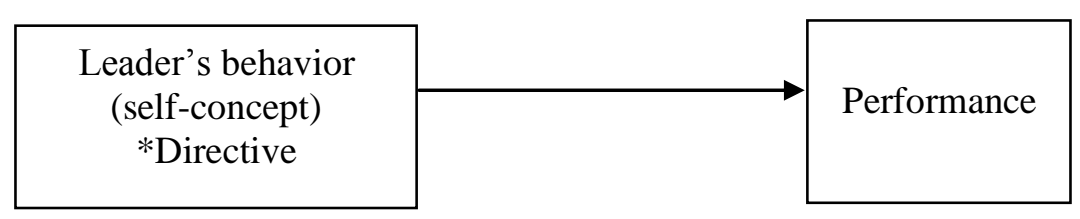

Figure 1. The effect of self-concept on performance 
Further Terence Mitchell (2005: 248) expressed the opinion that the motivation affects employee behavior that achievement. In the form of images can be seen as follows:

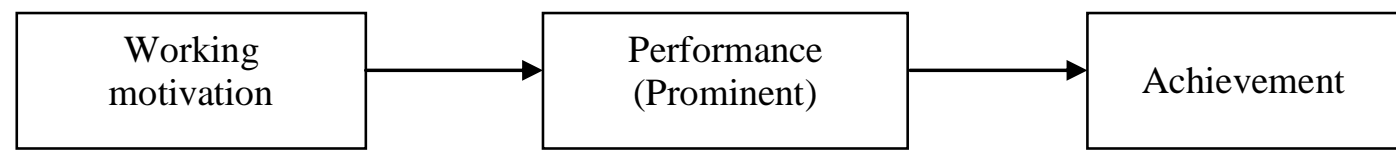

Figure 2. The effect of working motivation on performance

Anis Matta (2009: 20) states that the self-conceptis a personal consciousness is intact, strong, clear and deep vision and mission in life, the choice of a way of life along the principles and values that shape it, map the potential and competence themselves, the role of the region actualization and contributions, as well as charity fund plans featured the work of creating a feeling of self-concept focused in our individual consciousness structure.

According to Susana (2006: 19) states that 'if a man has a positive self-concept, it will form a high awards also to themselves, or to say that he has a high self esteem. The opinion can be interpreted that the self-concept includes self-esteem, confidence, ability and personality of a person and identity.

The concept of a person can progress and may change as circumstances and environmental influences. Susana et al (2006: 32) expressed the opinion that the selfconcept is the views and attitudes of individuals toward themselves. View of themselves related to the physical dimension, the individual characteristics and self-motivation. The view includes not only the individual strengths, but also the weakness of even the failure itself. This statement means that self-concept is the core of an individual's personality, which contains the physical aspect, character and self-motivated individual.

Another opinion from Steven A. Beebe and Susan J. Beebe (1999.37) states that "self concept plays in interpersonal communication with others, filtered by needs, values, belief, and attitudes". Which means, self-concept plays a role in interpersonal communication with others based on the needs, values, beliefs and attitudes, so as to see oneself, one needs to communicate with others as a reflection of yourself. While Puspasari (20007: 1) states that the concept itself is a result of how the process of knowing yourself is called self description. Starting from an assessment of the appearance of a pretty face, or body shape. Then developed to the introduction of non-physical self as the extent of my intelligence, it was as good if my behavior. 
Based on the description of the concept of self-constructs the analysis above, it can be concluded that self-concept is the ability in a person as a whole both in terms of personality, ability to work, willingness to work, sincerity work, adherence to the rules and purpose of his life. When applied to the concept of self-principal at a school, it would seem pertinent in charge to demonstrate its ability and sincerity in completing its tasks properly and responsibly.

Carl Heyell (2006: 165) states that Motivation refers to the degree or readiness of on organism to pursue some designated goal and implied the determination of the nature and locus of the forces inducing the degree of readiness. Which means that motivation refers to the level or personal readiness to achieve the planned objectives, and implement the situation with seriousness to achieve the level of personal preparedness in achieving its objectives. According Marihot Manulang AMH (2006: 166) Motivation is something that caused the stimulation or morale, simply can be defined as a morale booster. Mc Clelland (2005: 255-257) suggests that motivation needs are divided into three levels, namely the need for achievement, need for affiliation and need for power.

From the opinions above can be interpreted that motivation is possible very instrumental in improving the performance of the principal in a school. Because motivation is the basis of a person to do something to meet needs that will produce something. If a person is motivated to work, then he will exert every energy to reach the desired goal.

George Shinn (2003: 284) argues that people who are motivated must have the personal nature of the initiative is urging the push of a sluggish position toward the movement, change, act. While Stephen R. Covey (1997: 77) has another opinion that the highest level of human motivation is the feeling of the personal contribution and look at people as our most valuable asset. Hackman (1994: 557) also found employees with tasks that demand more responsibility motivated and satisfied with their position.

Based on the theories that have been presented above, it can be concluded that a person's motivation to work is a drive to get a higher fulfillment. Someone prefer jobs in which they have a personal responsibility and good discipline.

According to Spencer and Spencer (2002: 127) described as follows:

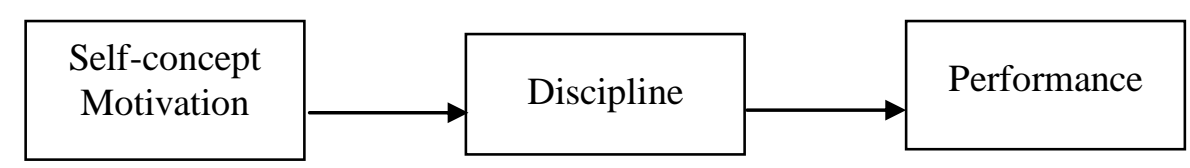


Figure 3. The influence of working motivation on Discipline

Discipline from the Latin word "disciplina", which means education modesty and spirituality, as well as character development. Discipline also means to teach and educate. In the work discipline, sense of discipline is the development of a proper attitude towards work tasks. Discipline in schools cater to all individuals in the school, including the principal. And principals act as a school disciplinarian.

James AF Stoner (1982: 51) expressed that the discipline is usually filed through a series of as many steps that need to deaden or resolve the issue: warning, reprimand, suspension, removal discipliner, demotion or dismissal as poling effort. Meanwhile, according to Keith Davis (1985-366) that Discipline is management action to enforce standards organization. Which is defined as the implementation of management to influence the organization's guidelines. Furthermore, Mangkunegara (2005 "129) states that self-discipline is a person's attempt to control their reaction to the situation that they do not enjoy, and someone attempt to overcome resentment.

Another opinion about discipline, ie, according Newstrom and Davis (2005: 129) stated that discipline is an action management that enforce or force the organization standards. Based on some of the theories that have been presented above, it can be concluded that a person's discipline is obedience to the rules of organization or institution that is expressed through obedience, implementation and concrete action someone with rules, procedures and work orders.

Associated with the discipline of the principal, which is the task of the school, which began with a time of discipline, discipline in the success of the task, is responsible for completing the task and compliance with guiding principles and perform well. According to Spencer and Spencer (127) is described as follows.

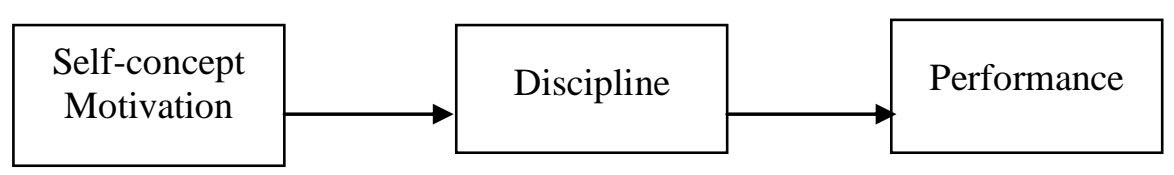

Figure 4. Effect on Performance Discipline

\section{METHOD}


The purposes of this study were designed as follows: 1) to determine whether self-concept has a direct effect on discipline, 2) to determine whether the motivation has a direct affect on discipline, 3) to determine whether discipline has a direct effect on performance, 4) to determine whether the self-concept has direct effect on performance, 5) to determine whether the motivation has a direct effect on performance, 6) to determine whether the self-concept has an indirect effect on performance but through discipline, and 7) to determine whether the motivation have an indirect effect on performance but through discipline.

The method used in this research was a survey method, with path analysis (path analysis) approach. Survey research is seen as a branch of scientific research in the social sciences. These procedures have been developed mainly by psychologists, sociologists, economists, scientists, politicians and statisticians.

Survey research was conducted in a population study, but the study is data from a sample taken from the population, and thus discovered the real phenomena or events that are relative and distribution as well as the relationship between variables.

As mentioned above, this study used a survey method with path analysis technique. The model can be seen as follows:

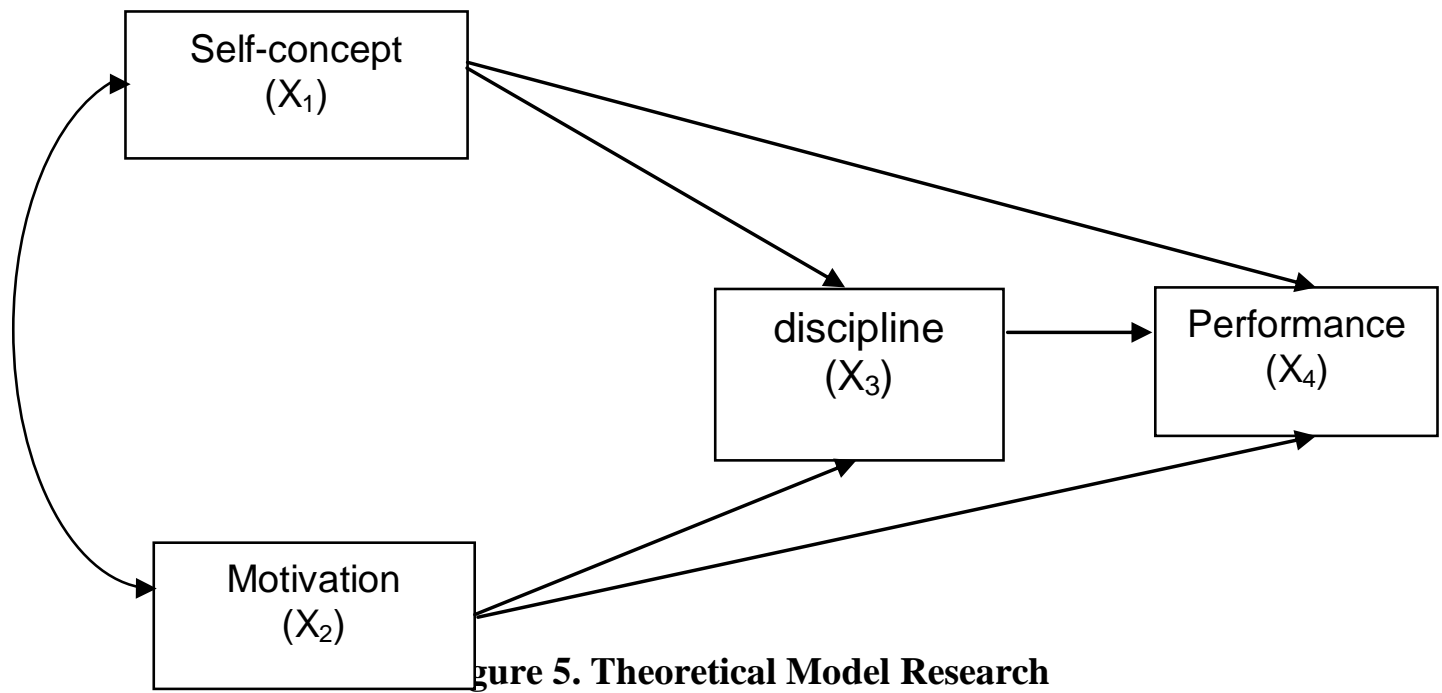

\section{RESEARCH RESULTS}

As an explanation and description of the data on the four variables of this study, the description in the form of mean, median, mode, frequency distribution and histogram of each variable will be presented. 
The data of the principal performance has a minimum 87 and maximum score 170, so the scores range was 83 (see Table 1). The data calculation results obtained the average value of 126.794 , the median $(\mathrm{Me})=125$, the mode $(\mathrm{Mo})=111$, standard deviation $(S D)=19.203$, and variance $=368.747$. Furthermore The data of the principal performance presented in the form of a frequency distribution as presented in Table 1 .

Table 1. Frequency Distribution of Principal's Performance

\begin{tabular}{|c|l|c|c|c|}
\hline No & Class interval & $\begin{array}{c}\text { Absolut } \\
\text { frequency }\end{array}$ & $\begin{array}{c}\text { Relative } \\
\text { frequency (\%) }\end{array}$ & $\begin{array}{c}\text { Cumulative } \\
\text { process (\%) }\end{array}$ \\
\hline 1 & $87-98$ & 3 & 4,762 & 4,762 \\
\hline 2 & $99-110$ & 6 & 9,524 & 14,286 \\
\hline 3 & $111-122$ & 12 & 19,048 & 33,333 \\
\hline 4 & $123-134$ & 23 & 36,508 & 69,841 \\
\hline 5 & $135-146$ & 10 & 15,873 & 85,714 \\
\hline 6 & $147-158$ & 6 & 9,524 & 95,238 \\
\hline 7 & $159-170$ & 3 & 4,762 & 100 \\
\hline & Total & 63 & 100,0 & \\
\hline
\end{tabular}

The frequency distribution above is based on the grouping data into seventh grade intervals. In addition, the above data shows that the score of performance with the highest number of respondents ranged from 123-134 (4th grade interval). It reflects the majority of respondents provide an assessment of performance based on statements made by grains of questionnaires given. However, if it turns out to be explored further other variables that affect performance, it is visible and can be verified by calculation path analysis against other exogenous variables, namely the concept of self-esteem, motivation, and discipline. Thus, in a performance that should pay attention to other influences. To make it clearer, the result is put in to diagram as can be seen as follows. 


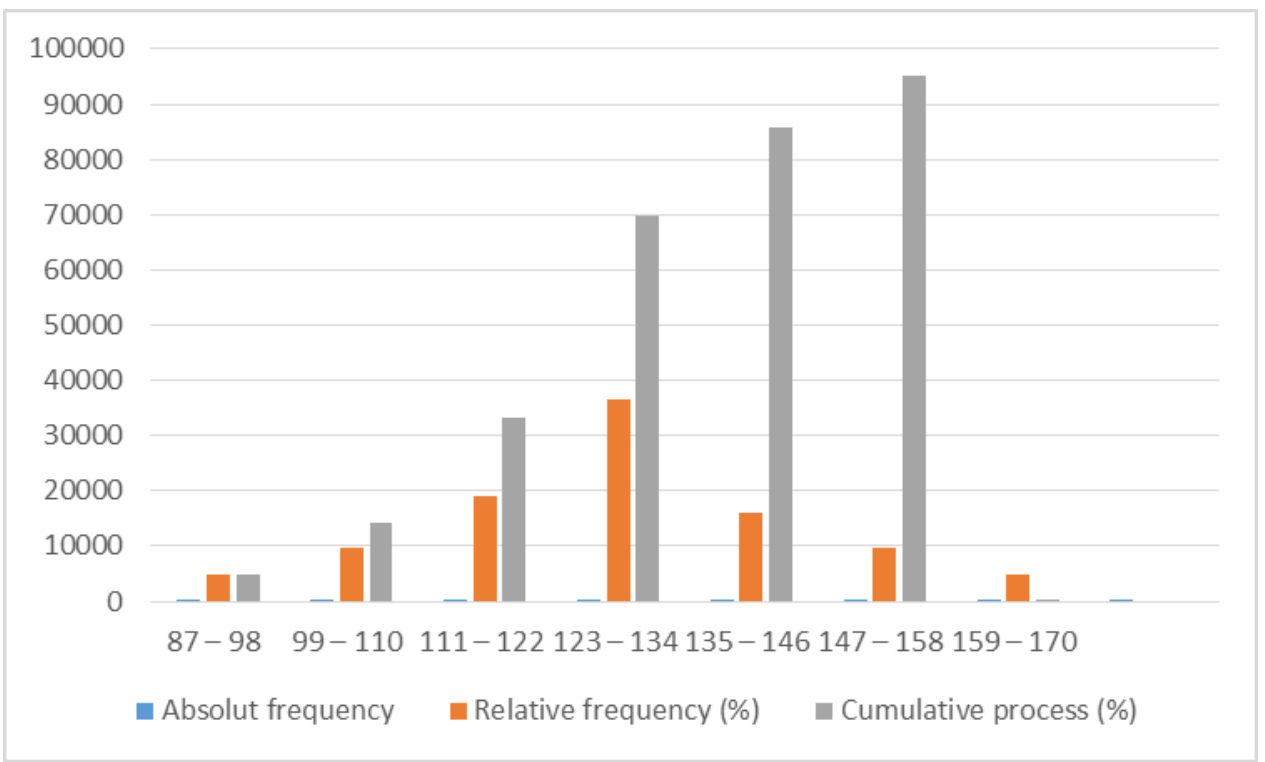

Picture 1. Diagram of Frequency Distribution of Principal's Performance

The data of self-concept has a minimum score of 52 and a maximum score of 135 so that the range of scores is 83 (see Table 2). The data calculation results obtained the average value of 94.683 , the median $(\mathrm{Me})=95$, the mode $(\mathrm{Mo})=77$, standard deviation $(\mathrm{SD})=17.011$, and variance $=289.382$. Furthermore, the self-concept data were presented in the form of frequency distribution as shown in Table 2.

Table 2. Frequency Distribution Self Concept

\begin{tabular}{|c|c|c|c|c|}
\hline No & Class interval & $\begin{array}{c}\text { Absolut } \\
\text { frequency }\end{array}$ & $\begin{array}{c}\text { Relative } \\
\text { frequency (\%) }\end{array}$ & $\begin{array}{c}\text { Cumulative } \\
\text { process (\%) }\end{array}$ \\
\hline 1 & $52-63$ & 2 & 3,175 & 3,175 \\
\hline 2 & $64-75$ & 5 & 7,937 & 11,111 \\
\hline 3 & $76-87$ & 9 & 14,286 & 25,397 \\
\hline 4 & $88-99$ & 23 & 36,508 & 61,905 \\
\hline 5 & $100-111$ & 14 & 22,222 & 84,127 \\
\hline 6 & $112-123$ & 7 & 11,111 & 95,238 \\
\hline 7 & $124-135$ & 3 & 4,762 & 100 \\
\hline & Total & 63 & 100,0 & \\
\hline
\end{tabular}

The frequency distribution of the above is based on grouping data into seventh grade intervals. In addition, the above data shows that the score of performance with the highest number of respondents ranged between 88-99 (4th grade interval). Based on the concept of self-distribution variable data presented in Table 2 above, indicating that the self-concept is needed to improve performance. To make it clearer, the result is put in to diagram as can be seen as follows. 


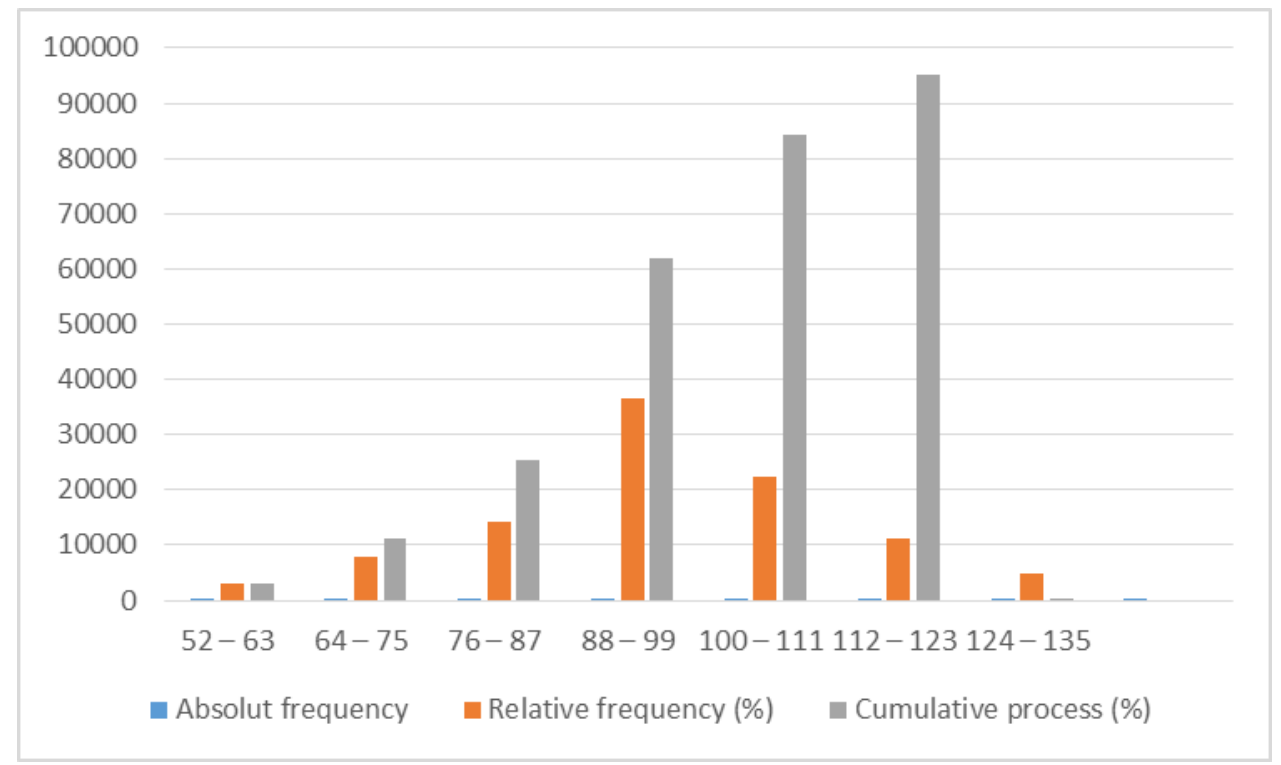

Picture 2. Diagram of Frequency Distribution Self Concept

Data Motivation has a minimum score of 76 and a maximum score of 159 so that the range of scores by 83 (see table 4.2). Results obtained data calculation average value of 116.444 , the median $(\mathrm{Me})=113$, the mode $(\mathrm{Mo})=113$, standard deviation $(\mathrm{SD})=$ 17.676 , and variance $=312.444$. Furthermore, the self-concept data were presented in the form of frequency distribution as presented in Table 3.

Table 3. Frequency Distribution of Motivation

\begin{tabular}{|c|l|c|c|c|}
\hline No & Class interval & $\begin{array}{c}\text { Absolut } \\
\text { frequency }\end{array}$ & $\begin{array}{c}\text { Relative } \\
\text { frequency (\%) }\end{array}$ & $\begin{array}{c}\text { Cumulative } \\
\text { process (\%) }\end{array}$ \\
\hline 1 & $76-87$ & 4 & 6,349 & 6,349 \\
\hline 2 & $88-99$ & 6 & 9,524 & 15,873 \\
\hline 3 & $100-111$ & 9 & 14,286 & 30,159 \\
\hline 4 & $112-123$ & 24 & 38,095 & 68,254 \\
\hline 5 & $124-135$ & 10 & 15,873 & 84,127 \\
\hline 6 & $136-147$ & 7 & 11,111 & 95,238 \\
\hline 7 & $148-159$ & 3 & 4,762 & 100 \\
\hline
\end{tabular}

The frequency distribution of the above is based on grouping data into seventh grade intervals. In addition, the above data shows that the score of motivation with the highest number of respondents ranged from 112-123 (4th grade interval). Based on the distribution of motivation variable data presented in Table 3 above, indicating that the motivation is needed to improve performance. To make it clearer, the result is put in to diagram as can be seen as follows. 


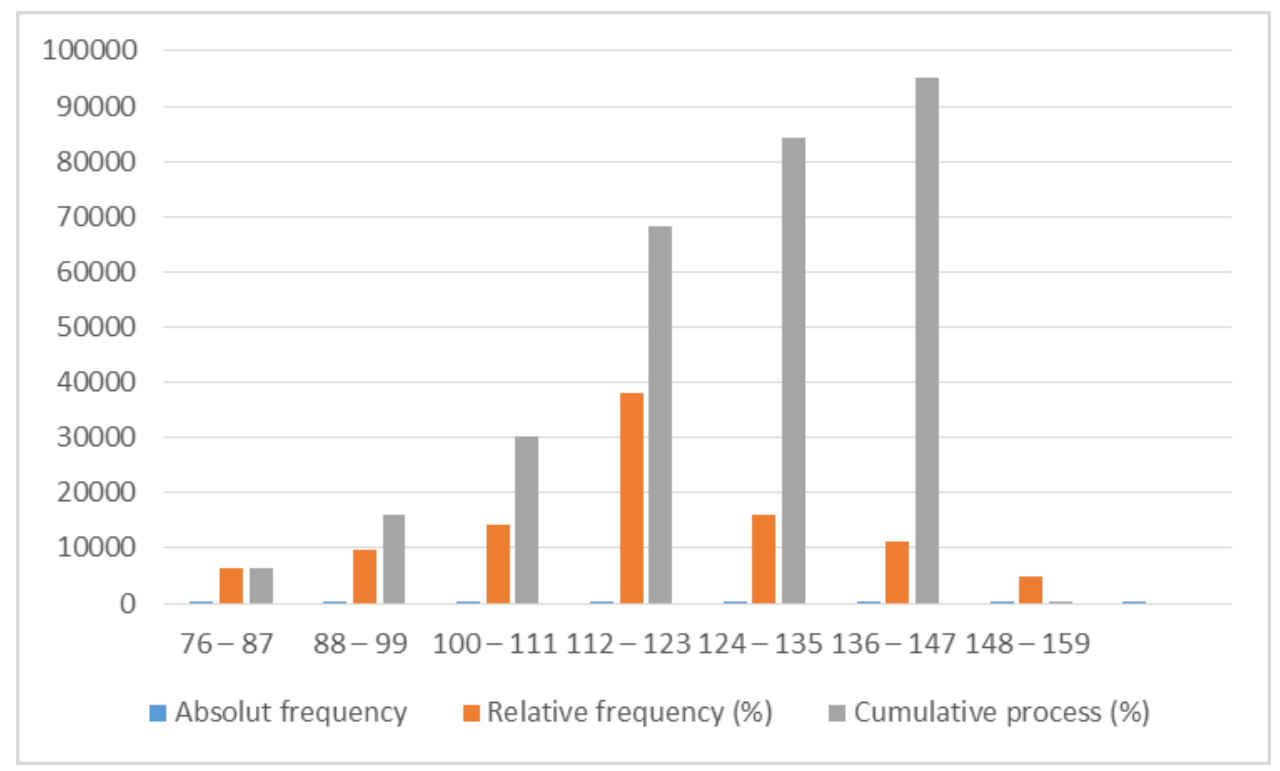

Picture 3. Diagram of Frequency Distribution Motivation

The data of discipline has a minimum score of 86 and a maximum score of 169 , so the range scores is 83 (see Table 4). The data calculation results obtained the average value of 124.286, the median $(\mathrm{Me})=124$, the mode $(\mathrm{Mo})=110$, standard deviation $(\mathrm{SD})$ $=18.389$, and variance $=338.143$. Furthermore, the data of discipline is presented in the form of a frequency distribution as shown in Table 4.

Table 4. Frequency Distribution of Discipline

\begin{tabular}{|c|l|c|c|c|}
\hline No & Class interval & $\begin{array}{c}\text { Absolut } \\
\text { frequency }\end{array}$ & $\begin{array}{c}\text { Relative } \\
\text { frequency (\%) }\end{array}$ & $\begin{array}{c}\text { Cumulative } \\
\text { process (\%) }\end{array}$ \\
\hline 1 & $86-97$ & 2 & 3,175 & 3,175 \\
\hline 2 & $98-109$ & 8 & 12,698 & 15,873 \\
\hline 3 & $110-121$ & 11 & 17,460 & 33,333 \\
\hline 4 & $122-133$ & 23 & 36,508 & 69,841 \\
\hline 5 & $134-145$ & 12 & 19,048 & 88,889 \\
\hline 6 & $146-157$ & 4 & 6,349 & 95,238 \\
\hline 7 & $158-169$ & 3 & 4,762 & 100 \\
\hline & Total & 63 & 100,0 & \\
\hline
\end{tabular}

The frequency distribution of the above table is based on grouping data into seventh grade intervals. In addition, the above data shows that the value of discipline score with the highest number of respondents ranged from 122-133 (4th grade interval). Based on the data distribution of discipline variables presented in Table 4 above, indicating that the discipline is needed to improve the performance. In Table 5 below can 
be seen recapitulation of the basic statistics of of all variables. To make it clearer, the result is put in to diagram as can be seen as follows.

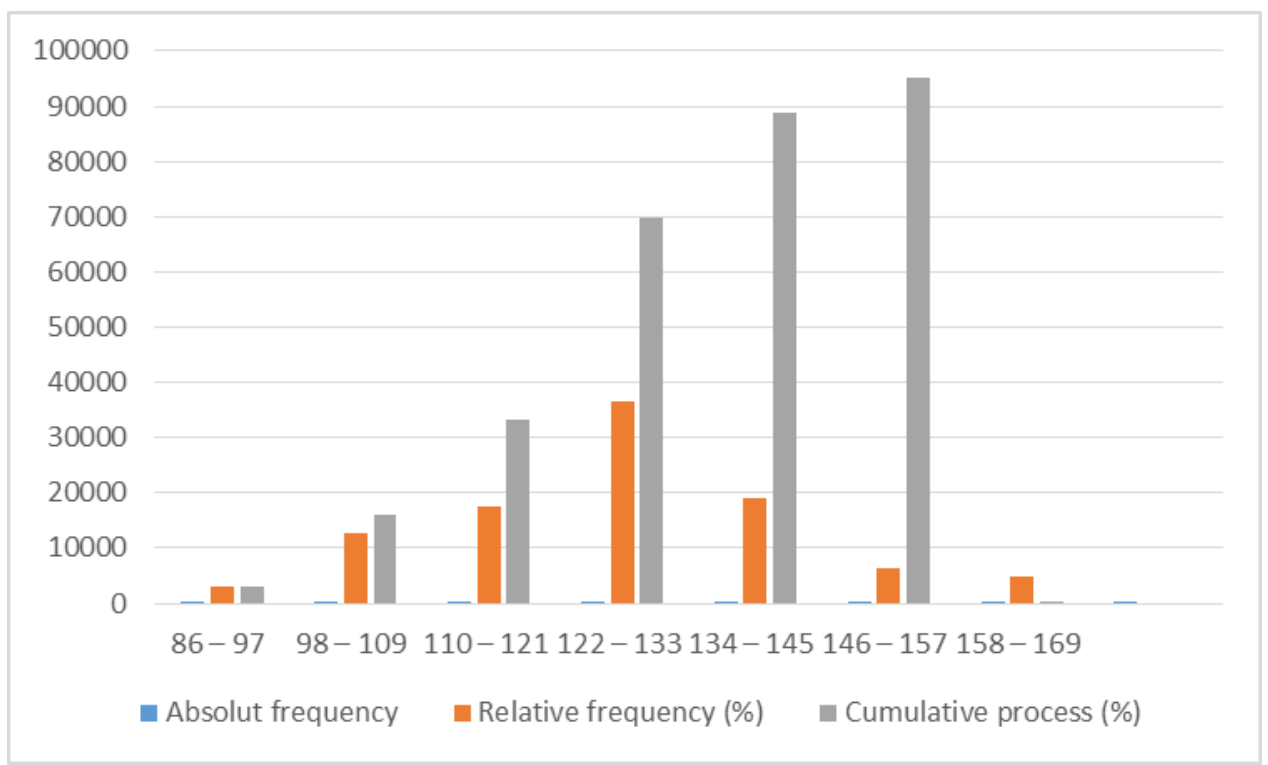

Picture 4. Diagram of Frequency Distribution Dicipline

In the following table will be shown the summary of the research data description among of all the research variables such as; performance, self-concept, motivation and discipline on their range of score, average, median, modus, standard deviation and variant.

Table 5. Summary of Data Description

\begin{tabular}{|l|c|c|c|c|c|c|}
\hline \multicolumn{1}{|c|}{ Variable } & $\begin{array}{c}\text { Score } \\
\text { Range }\end{array}$ & Average & Median & Modus & $\begin{array}{c}\text { Standar } \\
\text { deviation }\end{array}$ & Variants \\
\hline performance & 83 & 126,794 & 125 & 111 & 19,203 & 368,747 \\
\hline Self -concept & 83 & 94,683 & 95 & 77 & 17,011 & 289,382 \\
\hline Motivation & 83 & 116,444 & 113 & 113 & 17,676 & 312,444 \\
\hline Discipline & 83 & 124,286 & 124 & 110 & 18,389 & 338,143 \\
\hline
\end{tabular}

To make it easier to be understood, the following figure gives a more direct differences among of all the research variables such as; performance, self-concept, motivation and discipline on their range of score, average, median, modus, standard deviation and variant. 


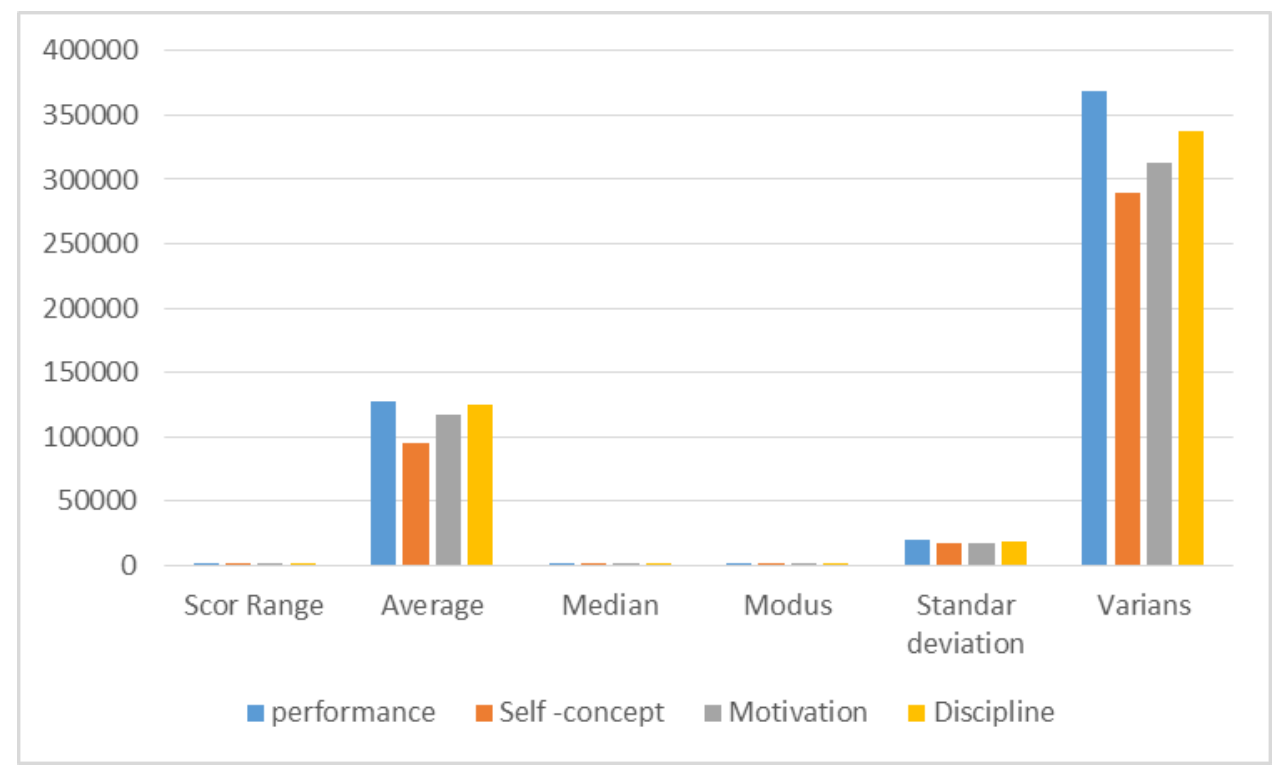

Picture 5. Diagram of Summary of Data Description

To conduct the path analysis of data from the research variables, must meet the following requirements: (1) the normality of the data; (2) homogeneity of variance groups score $\mathrm{Y}$ grouped by similarity of data of $\mathrm{X}$ variable; (3) linearity and significance of regression and correlation. Here are described the test results of the three requirements of the analysis.

The normality test was conducted to test whether the data were normally distributed or not. The test criteria are normal distribution of data if $\mathrm{H}_{0}$ is accepted and is not normal if $\mathrm{H}_{0}$ is rejected. Kolmogorov-Smirnov test was used to test the normality requirements of the data. The testing criteria as follows:

$$
\begin{aligned}
& H_{0}, \text { if } A_{\max }<D_{\text {table }} \\
& H_{0} \text {, if } A_{\max } D_{\text {table }}
\end{aligned}
$$

The Normality test was counted by calculating the value of a1 and a 2 to perform calculations on the value of score $(\mathrm{X})$, frequency $(\mathrm{F})$, the proportion $(\mathrm{P})$, Cumulative Proportion (KP), the value $\mathrm{Z}_{\text {count }}(\mathrm{Zx})$, and the value $\mathrm{Z}_{\text {table. }}$ After the value of a1 and a2 is obtained, then the maximum absolute value of a1 and a 2 are found. The highest value was selected to be the $\mathrm{a}_{\max }$. If the value of $\mathrm{A}_{\max }<\mathrm{D}_{\text {table, }}$, so the data was normally distributed, otherwise if $\mathrm{a}_{\max } \geq \mathrm{D}_{\text {table }}$ then the data was not normally distributed.

To make make it easy, the calculation above can be counted using the SPSS program. 
$A_{\max }$ values obtained from the calculation of 0,100 , while the value of $D_{\text {table }}$ for $\alpha=0,05$ was 0.171 and for $\alpha=0,01$ was 0.205 . Thus the value of $\mathrm{A}_{\max }<\mathrm{D}_{\text {table }}$, so it can be said that the data the Principal Performance were normally distributed.

$\mathrm{A}_{\max }$ values obtained from the calculation results and the result was 0.062 , while the value of $\mathrm{D}_{\text {table }}$ for $\alpha=0,05$ was 0.171 and to $\alpha=0,01$ was 0.205 . Thus the value of $A_{\max }<D_{\text {table }}$, so it can be said that the data of self-concept were normally distributed.

$\mathrm{A}_{\max }$ values obtained from the calculation results and the result was 0.062 , while the value of $\mathrm{D}_{\text {table }}$ for $\alpha=0,05$ was 0.171 and to $\alpha=0,01$ was 0.205 . Thus the value of $\mathrm{A}_{\max }<\mathrm{D}_{\text {table, }}$, so it can be said that the data of motivation were normally distributed.

$A_{\max }$ values obtained from the calculation results and the result was 0.062 , while the value of $\mathrm{D}_{\text {table }}$ for $\alpha=0,05$ was 0.171 and to $\alpha=0,01$ was 0.205 . Thus the value of $A_{\max }<D_{\text {table }}$, so it can be said that the data of diciplin were normally distributed.

The Summary of the normality test calculation results can be seen in the following table.

Table 6. Summary Analysis Normality Test

\begin{tabular}{|c|c|c|c|c|c|}
\hline \multirow{2}{*}{ Variable } & \multirow{2}{*}{$\mathbf{n}$} & \multirow[b]{2}{*}{$\mathbf{a}_{\max }$} & \multicolumn{2}{|c|}{$D_{\text {table }}$} & \multirow{2}{*}{ Explanation } \\
\hline & & & $\alpha=0,05$ & $\alpha=0,01$ & \\
\hline School Principle & 63 & 0,100 & 0,171 & 0,205 & Normal \\
\hline Self-concept & 63 & 0,062 & 0,171 & 0,205 & Normal \\
\hline Motivation & 63 & 0,099 & 0,171 & 0,205 & Normal \\
\hline Dicipline & 63 & 0,117 & 0,171 & 0,205 & Normal \\
\hline
\end{tabular}

The homogeneity of variance test was intended to test the homogeneity of variance between groups score the dependent variable $(\mathrm{Y})$, which are grouped by similarity value of the independent variable (X). Tests conducted by the homogeneity of variance Bartlett's test.

The testing process adopted is to create a first data grouping $\mathrm{X} . \mathrm{Y}$ is then calculated based on common values of $\mathrm{dk}, 1 / \mathrm{dk}$, variance of $\mathrm{Si}^{2}, \log \mathrm{Si}^{2},(\mathrm{dk}) \log \mathrm{SI}^{2}$, (dk) $\mathrm{SI}^{2}$. From the values, the values, the score of $\mathrm{x}^{2}$ was calculated and the result is called $x^{2}$ count . The test criteria are as follows:

$\mathrm{HO}$ is accepted if

$\mathrm{H} 0$ is rejected if

The testing results of homogeneity variance test of the Principal Performance on self-concept values obtained of $X_{\text {count. }}^{2}=16,488$. The score of $X_{\text {table }}^{2}$ with the $\mathrm{dk}=46$ at $\alpha=0,05$ was 58.365 , and to $\alpha=0,01$ was amounted to 66.618. Therefore, 
$x_{\text {count }}^{2}<x_{\text {table }}^{2}, \mathrm{H}_{0}$ is accepted. This means that the variances group of the principal Performance on self-concept is homogeneous.

The testing results of homogeneity variance test of the Principal Performance on discipline was obtained of $X_{\text {count. }}^{2}=7.050$. The score of $X_{\text {table }}^{2}$ with the $\mathrm{dk}=31$ at $\alpha=0,05$ was 44,989 , and to $\alpha=0,01$ was amounted to 52.196. Therefore, $x_{\text {count }}^{2}<x^{2}$ table, $\mathrm{H}_{0}$ is accepted. This means that the variances group of the principal Performance on discipline is homogeneous.

The testing results of homogeneity variance test of self-concept on motivation was obtained of $\mathrm{X}_{\text {count. }}^{2}=17.0621$. The score of $\mathrm{X}_{\text {table }}^{2}$ with the $\mathrm{dk}=46$ at $\alpha=0,05$ was 58.365, and to $\alpha=0,01$ was amounted to 66.618. Therefore, $x_{\text {count }}^{2}<x^{2}{ }_{\text {table }}, \mathrm{H}_{0}$ is accepted. This means that the variances group of the self-concept on motivation is homogeneous.

The testing results of homogeneity variance test of motivation on discipline was obtained of $\mathrm{X}_{\text {count. }}^{2}=10.949$. The score of $\mathrm{X}_{\text {table }}^{2}$ with the $\mathrm{dk}=37$ at $\alpha=0,05$ was 48.637, and to $\alpha=0,01$ was amounted to 56.108 . Therefore, $x_{\text {count }}^{2}<x^{2}$ table, $\mathrm{H}_{0}$ is accepted. This means that the variances group of the motivation on disciplines is homogeneous.

The overall homogeneity of variance test results are summarized in the following table.

Table 7. Summary Homogeneity Test Analysis

\begin{tabular}{|l|c|c|c|c|c|}
\hline \multirow{2}{*}{ Variabel } & \multirow{2}{*}{$\mathrm{dk}$} & \multirow{2}{*}{$X_{\text {hitung }}^{2}$} & \multicolumn{2}{c|}{$X_{\text {tabel }}^{2}$} & \multirow{2}{*}{ Keterangan } \\
\cline { 4 - 5 } & & $\alpha=0,05$ & $\alpha=0,01$ & \\
\hline $\begin{array}{l}\text { The school pricipal } \\
\text { performance on self- } \\
\text { concept }\end{array}$ & 46 & 16,488 & 58,365 & 66,618 & Homogen \\
\hline $\begin{array}{l}\text { The school pricipal } \\
\text { performance on } \\
\text { Motivation }\end{array}$ & 37 & 13,831 & 48,637 & 56,108 & Homogen \\
\hline $\begin{array}{l}\text { The school pricipal } \\
\text { performance }\end{array}$ & 31 & 7,050 & 44,989 & 52,196 & Homogen \\
\hline Diciplines or motivation & 46 & 17,621 & 58,365 & 66,618 & Homogen \\
\hline motivation and diciplene & 37 & 10,949 & 48,637 & 56,108 & Homogen \\
\hline
\end{tabular}

The calculation of simple regression analysis based on data variables on performance on Self-Concept generate the directions of $\mathrm{b}$ regression amount 1.079 and the a constant of 24.631. Thus the equation of the regression was 
$Y_{4}=24,631+1,079 X_{1}$. To determine the significance and linearity regression equation of $\mathrm{F}$ test and calculation results as presented in the following table:

Table 8. ANOVA Significance and Linearity Regression

\begin{tabular}{|c|c|c|c|c|c|c|}
\hline \multirow{2}{*}{$\begin{array}{l}\text { Variant } \\
\text { sources }\end{array}$} & \multirow{2}{*}{$\mathrm{dB}$} & \multirow{2}{*}{ JK } & \multirow{2}{*}{ RJK } & \multirow{2}{*}{ Fo } & \multicolumn{2}{|c|}{$\mathrm{F}_{\text {table }}$} \\
\hline & & & & & $\alpha 0,05$ & $\alpha \quad 0,01$ \\
\hline Total & 63 & 1035690 & - & - & - & - \\
\hline Regresi (a) & 1 & 1012827,683 & 1012827,683 & - & - & - \\
\hline Regresi (b/a) & 1 & 20900,093 & 20900,093 & $649,717 * *$ & 3,998 & 7,072 \\
\hline remain & 61 & 1962,224 & 32,168 & - & - & - \\
\hline Suitable Tuna & 45 & 1367,757 & 30,395 & $0,818^{\mathrm{ns}}$ & 2,145 & 2,985 \\
\hline Galat & 16 & 594,467 & 37,154 & & & \\
\hline
\end{tabular}

Information:

$* *$ very significant regression $\left(\mathrm{F}_{\text {count }}=649.717>\mathrm{F}_{\text {table }}=7.072\right.$ at $\left.\alpha=0,01\right)$

Ns = non-significant, linear-shaped regression $\left(\mathrm{F}_{\text {test }}=0.818<\mathrm{F}_{\text {table }}=2,985\right.$ at $\alpha=0,01)$

$\mathrm{df}=$ degrees of freedom

$\mathrm{JK}=$ Sum of Squares

RJK = Average Number Squares

The table above shows the price of $F_{\text {count }}$ of regression was 649.717 , while the value of $\mathrm{F}_{\text {table }}$ with $\mathrm{dk}$ numerator 1 and denominator $\mathrm{df}=61$ at $\alpha=0,01$ was 7.072. Thus $\mathrm{F}_{\text {count }}>\mathrm{F}_{\text {table }}$ at $=0.01$ which indicates that the regression equation is very significant.

While the price of $\mathrm{F}_{\text {count }}$ suitable obtained at 0.818 and price $\mathrm{F}_{\text {table }}$ with $45 \mathrm{dk}$ numerator was 45 and dk denominator was $16 \alpha=0,01$ was 2,985 so $\mathrm{F}_{\text {count }}<\mathrm{F}_{\text {table. Thus, }}$. we can conclude that the form of regression $Y_{4}=24,631+1,079 X$ is linear.

The correlation coefficient between Self-Concept variable with Principal performance variables was 0.983 . Significance test of correlation coefficient was obtained by using $\mathrm{t}$ test was 41.723 , the price of $\mathrm{t}_{\text {table }}$ with $\mathrm{dk} 61$, thus $\alpha=0,01$ was 1,670 and on $\alpha=0,01$ for 2,985 . Because $\mathrm{t}_{\text {table }}>\mathrm{t}_{\text {table }}$ on $\alpha=0,01$ so the correlation coefficient between the Self-Concept and Principal Performance is very significant. The determination coefficient was 0.914 . It means that an amount of 91.40 variance, the Principal Performance was determined by Self-Concept. 
The calculation of simple regression analysis based on variables of the data of performance on motivation generate the directions of $\mathrm{b}$ regression about 1.046 and the a constanta was 4,994. Thus the regression equation was $Y_{4}=4,994+1,046 X$.

\section{DISCUSSION}

From the calculation and testing of the path coefficients result, whether on both the initial structural model and the modified structural model, it can be explained that the results of the research hypothesis testing as follows:

The hypothesis tested were:

$$
\begin{aligned}
& \mathrm{H}_{0}: \mathrm{p} 31=0 \\
& \mathrm{H}_{1}: \mathrm{p} 31>0
\end{aligned}
$$

The calculation result obtained by the path coefficient $\left({ }_{\mathrm{p}} 31\right)=0.334$ with $\mathrm{t}_{\text {count }}=$ 3,634 and $t_{\text {table }}$ on by 2,658 , thus $t$ is greater than $t$ table so that the path coefficient is very significant. This means that the Self-concept have a direct impact positively on Discipline.

The hypothesis tested were:

$\mathrm{H} 0: \mathrm{p} 32=0$

$\mathrm{H} 1: \mathrm{p} 32>0$

The calculation result obtained by the path coefficient $(\mathrm{p} 32)=0.659$ with $\mathrm{t}_{\text {count }}=$ 3,634 and ttable on $\alpha=0,01$, was 2.658 , thus $\mathrm{t}_{\text {count }}$ is greater than $\mathrm{t}_{\text {table, }}$ so the path coefficient is very significant. This means that the motivation has a positive direct effect on Discipline.

The hypothesis tested were:

$$
\begin{aligned}
& \mathrm{H}_{0}:{ }_{\mathrm{P}} 43=0 \\
& \mathrm{H}_{1}: \mathrm{p}_{\mathrm{P}} 43>0
\end{aligned}
$$

The calculation result obtained by the path coefficient $(\mathrm{p} 43)=0.642$ with $\mathrm{t}_{\text {count }}=$ 3,634 and ttable on $\alpha=0,01$, was 2.658 , thus $t_{\text {count }}$ is greater than $t_{\text {table, }}$ so the path coefficient is very significant. This means that the disciplines has a positive direct effect on school principal performance.

The hypothesis tested were:

$$
\begin{aligned}
& \mathrm{H}_{\mathrm{o}}: \mathrm{p} 41=0 \\
& \mathrm{H}_{1}: \mathrm{p} 41>0
\end{aligned}
$$


The calculation result obtained by the path coefficient $(\mathrm{P} 41)=0.160$ with $\mathrm{t}_{\text {count }}=$ 1.120 and $\mathrm{t}_{\text {table }}$ on $\alpha=0,01$, was 2.658 , thus $\mathrm{t}_{\text {count }}$ on $\alpha=0,05$ was 1.999 , so $\mathrm{t}_{\text {count }}$ is smaller than $t_{\text {table, }}$ so the path coefficient is not significant. This means that the selfconcept has an effect on school principal performance.

The hypothesis tested were:

$\mathrm{H}_{\mathrm{o}}: \mathrm{p} 42=0$

$\mathrm{H}_{\mathrm{o}}: \mathrm{p} 42>0$

The calculation result obtained by the path coefficient $\left({ }_{\mathrm{p}} 42\right)=0.175$ with $\mathrm{t}_{\text {count }}=$ 0.992 and $\mathrm{t}_{\text {table }}$ on $\alpha=0,01$, was 2.658 , thus $\mathrm{t}_{\text {table }}$ on $\alpha=0,05$ was 1.999 , so $\mathrm{t}_{\text {count }}$ is smaller than $t_{\text {table, }}$ so the path coefficient is not significant. This means that the motivation has an effect on the school principal performance..

\section{CONCLUSION}

Based on the results of research and data processing as described in the chapters above. So this study can be summarized as follows; 1) The self-concept direct effect on discipline, 2) Motivation direct effect on discipline, 3) Discipline direct effect on performance, 4) The concept itself affect the performance through discipline, 5) Motivation influence performance through discipline.

As described above, this study analyzed four (4) variables. First to third variable is the exogenous variables indicate that self-concept variables have an influence on performance through discipline. Then discipline directly affects the performance. Thus it can be concluded that the variable of self-concept, motivation and discipline are the dominant variables that affect the performance of the Principal of State Elementary School in Jagakarsa sub-district, South Jakarta.

\section{REFERENCES}

Anis Matta, Delapan Mata Air Kecemerlanga, Jakarta : Tarbawi Press, 2009.

Anna Keliat Budi, Gangguan Konsep Diri, Jakarta : EGC, 1992.

Anwar Prabu Mangkunegara, Perencanaan dan Pengembangan Suber Daya Manusia, Bandung : Aditama, 2003. 
Anwar Prabu Mangkunegara Manajemen Sumber Daya Manusia Perusahaan Bandung : Remaja Rosdakarya, 2005.

Arikunto Suharsismi, Prosedur Penelitian, Jakarta : Rineka Cipta, 2002.

Ashar sunyoto Munandar, Psikologi Industri dan Organisasi, Jakarta:UI Press. 2001.

Covey Stephen R, Principle Centered Leadership, Ahli Bahasa Julius Sanjaya Dan Lyndon Saputra : Bina Aksara, 1997.

Covey Stephen R, The 8 th Habit " Melampaui Efektivitas, Menggapai Keagungan " Jakarta : Gramedia Pustaka Utama, 2005.

Depdiknas, Undang-undang Republik Indonesia No.20 tahun 2003, Tentang Sistem Pendidikan Nasional : Depdiknas, 2003.

Grote Dick, The Complete Guide to Performance Appraisal, New york: Amerikan Management Association, 1991.

James AF Stoner, Management, Jakarta : Erlangga, 1982.

James AF Stoner dan R. Edward Freeman, Manajemen, Jakarta : Intermedia. 1994.

Karlinger Fred N, Asas-asas Penelitian Behavioral, Yogyakarta: Gajah Mada University Press, 2006.

Manulang Marihot AMH, Manajemen Personalia, Yogyakarta: Gajah Mada University Press, 2006.

Mulyasa Ashar Sunyoto, Psikologi Industri dan Organisasi, Jakarta: University Indonesia Press, 2004.

Puspasari Amaryllia, Mengukur Konsep Diri, Jakarta: Elex Media Komputindo Gramedia, 2007.

Richard S. William, Managing Employee Performance "Design and Implementation in Organizations ”, Internasional Business, 2002.

Robert Kreitner dan Angelo Kinicki, Organizational Behavior, Jakarta: Salemba Empat, 2005

Robert Kreitner, Perilaku Organisasi, Jakarta : Mc. Graw Hill Salemba Empat: 2005

Robbins, Stephen P, Perilaku Organisasi, Terjemahan Benyamin Molan, Jakarta : Indeks Gramedia, 2003.

Robinson Ricard. B.JR, Manajemen Strategis, Terjemahan Agus Maulana dan Lyndon Saputra, Jakarta : Binarupa Aksara, 1997 
Shinn George, Miracle of Motivation, Alih Bahasa Hari Suminto dan Lyndon Saputra, Batam : Interaksara, 2003.

Sisson, Kkeith, Personal Management : At Comprehensive Guide to Theory \& Practice in Britain, Oxford : Blackwell Publisher, 1994

Steven R Covey, The 8 th Habit " Melampaui Efektivitas Menggapai Keagungan ", Jakarta : Gramedia Pustaka Utama, 2005

Steven R Cohey, Principle Centered Leadership, Alih Bahasa Julius Sanjaya dan Lyndon Saputra, Jakarta : Binarupa Aksara, 1997

Stoner James AF,Manajemen Jilid 1,Terjemahan Anatrikso dkk dan Gunawan Hutauruk, Jakarta : Erlangga, 1986.

Stoner James AF dan R. Edward Fremmen, Manajemen Jilid 1, Alih Bahasa Wilhemus W, Bakowatun dan Benyamin Molan, Jakarta: Intermedia 1994

Soedijarto, Menuju Pendidikan Nasional Yang Relevan dan Bermutu, Jakarta Balai Pustaka, 1993

Soedijarto, Pendidikan Nasional Sebagai Wahana Mencerdaskan Kehidupan Bangsa dan Membangun Peradaban Negara - Negara, Jakarta : Center For Infromation and National Policy Studies ( CINAPS), 2000

Susana,Tjipto,Konsep Diri Positif : $\quad$ Menentukan Prestasi Anak, Yogyakarta Penerbit Kanisius, 2006.

Toto Tasmara, Spiritual Centered Leadership, Jakarta : Gema Insani, 2006

Williams Richard S, Managing Employee Performance Design and Implementation in Organizations, International Thomson Business, 2002 